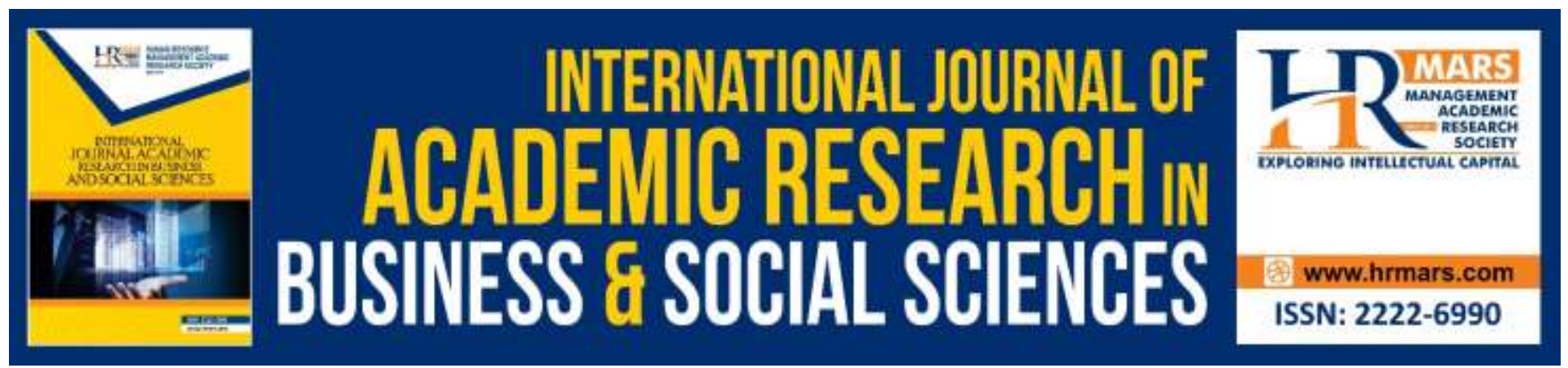

\title{
Consumer Attitude towards Online Shopping Activities of Halal Cosmetic Products in Malaysia
}

Roszi Naszariah Nasni Naseri, Norfaridatul Akmaliah Othman, Mohammed Hariri Bakri, Nik Rahila Wan Ibrahim

To Link this Article: http://dx.doi.org/10.6007/IJARBSS/v10-i5/7178

DOI:10.6007/IJARBSS/v10-i5/7178

Received: 07 March 2020, Revised: 10 April 2020, Accepted: 26 April 2020

Published Online: 05 May 2020

In-Text Citation: (Naseri et al., 2020)

To Cite this Article: Naseri, R. N. N., Othman, N. A., Bakri, M. H., \& Ibrahim, N. R. W. (2020). Consumer Attitude towards Online Shopping Activities of Halal Cosmetic Products in Malaysia. International Journal of Academic Research in Business and Social Science, 10(5), 114-126.

Copyright: @ 2020 The Author(s)

Published by Human Resource Management Academic Research Society (www.hrmars.com)

This article is published under the Creative Commons Attribution (CC BY 4.0) license. Anyone may reproduce, distribute, translate and create derivative works of this article (for both commercial and non-commercial purposes), subject to full attribution to the original publication and authors. The full terms of this license may be seen

at: http://creativecommons.org/licences/by/4.0/legalcode

Vol. 10, No. 5, 2020, Pg. $114-126$

http://hrmars.com/index.php/pages/detail/IJARBSS

JOURNAL HOMEPAGE

Full Terms \& Conditions of access and use can be found at http://hrmars.com/index.php/pages/detail/publication-ethics 


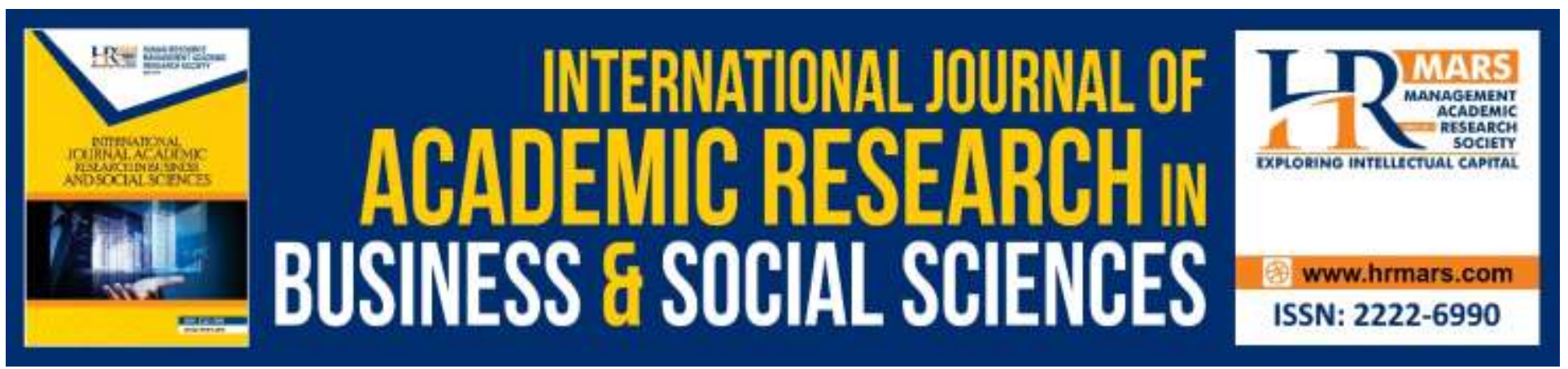

\title{
Consumer Attitude towards Online Shopping Activities of Halal Cosmetic Products in Malaysia
}

\author{
Roszi Naszariah Nasni Naseri \\ Faculty of Technology Management \& Technopreneurship, Universiti Teknikal Malaysia Melaka \\ 75350 Ayer Keroh, Melaka, MALAYSIA, Universiti Teknologi MARA Melaka, Malaysia \\ E-mail: roszinasni@gmail.com \\ Norfaridatul Akmaliah Othman \\ Faculty of Technology Management \& Technopreneurship, Universiti Teknikal Malaysia Melaka, \\ 75350 Ayer Keroh, Melaka, MALAYSIA \\ Mohammed Hariri Bakri \\ Faculty of Technology Management \& Technopreneurship, Universiti Teknikal Malaysia Melaka \\ 75350 Ayer Keroh, Melaka, MALAYSIA \\ Nik Rahila Wan Ibrahim \\ Centre for Languages and Human Development, Universiti Teknikal Malaysia Melaka \\ 76100 Durian Tunggal, Melaka, MALAYSIA
}

\begin{abstract}
The internet has become a highly used medium for businesses that are engaged in online shopping. One popular online product is halal cosmetics. However, it is found that the sales of these products are low, despite much effort done by the Malaysian government to promote this industry. Thus, this study examines the attitude of consumers towards their intention of online purchase of halal cosmetic products. A questionnaire was administered to a group of 100 respondents using the random sampling method. Data were analysed via the Partial Least Square-Structural Equation Modelling (PLS-SEM) approach to examine the posited research hypotheses. The PLS-SEM approach revealed that the attitude of consumers does affect the consumers' intention in purchasing online. The findings reveal that the impact of consumer attitude towards their online purchase intentions trails behind developed countries. Thus, further research should be implemented in order to better understand what constitutes consumer attitudes towards online shopping in Malaysia.
\end{abstract}

Keywords: Consumer Attitude, Purchase Intention, Online Shopping, Halal Cosmetic Products, Theory of Reasoned Action, Malaysia. 
INTERNATIONAL JOURNAL OF ACADEMIC RESEARCH IN BUSINESS AND SOCIAL SCIENCES

Vol. 10, No. 5, May, 2020, E-ISSN: 2222-6990 @ 2020 HRMARS

\section{Introduction}

Online shopping is a form of e-commerce where many businesses are engaged in. Based on the Malaysian Communication and Multimedia Commission (MCMC) survey in 2017, online shopping is ranked 11th among the top 15 reasons why Malaysians access the Internet.

There are varieties of products that are sold on the internet such as clothes, furniture, computer equipment and so on. In 2019, a staggering $\$ 771.0$ million was spent on Fashion and beauty alone (Digital, 2019). One popular online purchasing product is cosmetic products. More specifically, it is halal cosmetics products that have become an expanding branch of cosmetic products. Halal-certified products have created the leading demand for products in beauty and personal care amongst the Muslim population in Malaysia (Euromonitor, 2017).

The growing market size of Muslim population internationally, which may reach $7.4 \%$ billion in 2050 (Pew Research, 2018) is expected to create more opportunities for the halal cosmetics and personal care industry. The rising economic power of Muslim countries has influenced them to spend more on beauty and personal goods (Swidi et al. 2010).

There is a lot of effort done by Malaysian Government to promote the industry. In 2014 alone, Malaysia External Trade Development Corporation (MATRADE) identified 147 halal promotion activities that involved 46 markets (Saloma, 2014). Malaysia was listed as among the top 10 producers of Halal cosmetic in the world. Among the top homegrown brands in Halal cosmetics and skincare are SimplySiti, Pretty Suci, So.Lek, Nurrasysa, dUCk Cosmetics and Elhajj Halal (Nadia, 2019).

According to Mordor Intelligence, (2019) the distribution of halal cosmetics goes to supermarkets, specialty stores, convenience stores, online stores and others. However, it is a surprise to find that the study by Euromonitor (2017) showed that the sales of halal cosmetic products via online stores is still low as compared to other distribution channel. This is because of the less known factors, on what determines online shopping and consuming attitude (Muniandy, Al-Mamun, Permarupan \& Zainol, 2014). Therefore, this study will attempt to unravel the relationship between these two factors when it comes to online shopping. With this in mind the objective of this study is:

- to establish the relationship between consumer attitude and online purchase intention of halal cosmetic products.

\section{Literature Review}

\section{Overview of Online Purchase Intention}

An intention can be defined as subjective judgments about how a person will behave in the future (Blackwell et al. 2001). Venkatesh et al. (2008) described behaviour as an individual's overall affective reaction to use a particular system. A behaviour can be negative or positive, and it is based on the consumers' perception towards it (Bauer et al. 2005; Chowdhury et al. 2006). A positive or negative attitude depends on situation or factors that influence them during the time they want to perform a particular behaviour (Carroll, et al. 2007; Lee et al. 2006).

An intention may be a key informative indication of a particular business to succeed while retaining its customers (Blackwell et al. 2001). It is common that consumers usually do what they intend to do. From the perspective of marketing, the purchase intention is part of consumers' intention (Blackwell et al. 2001) and very helpful to act as an indicator for many marketing activities (Altuna \& Konuk, 2009).

A purchase intention reflects what consumers think they will buy in future to fulfil their needs and wants (Blackwell et al. 2001). Online purchase intention is a significant predictor to an actual 
INTERNATIONAL JOURNAL OF ACADEMIC RESEARCH IN BUSINESS AND SOCIAL SCIENCES

Vol. 10, No. 5, May, 2020, E-ISSN: 2222-6990 @ 2020 HRMARS

purchase (Pavlou 2003). However, consumers' intention may change due to unanticipated circumstances. Thus, it is important for businesses to take proactive measures to ensure that their customers have a positive perception about products and services (Lamb et al. 2014).

The study by O'Cass and Fenech (2003); and Sajad and Khairuzzaman (2012) suggest that online retailers need to focus on the internet user's online purchasing intention as a strong mechanism to attract them. Therefore, it is important to understand consumers' purchase intentions within online trade activities.

Several studies investigating online purchase intentions made use of the Theory of Reasoned Action or Theory of Planned Behavior in order to explain future online purchase intentions (Raman, 2019; Chin and Goh, 2017; Butt et al., 2017). The theory of reasoned action (TRA) explains the relationship between attitude and behaviour (Ajzen, 1991) and suggests that human beings are rational individuals with the ability to process decision-making information. TRA explains that attitude is a psychological tendency to form an evaluation in favour or against a particular object to some degree and that behaviour is a function of an individual's attitude.

While the Theory of Planned Behaviour (TPB) by Ajzen (1991) provides a link between consumer attitudes and behaviour, behavioural belief is concerned with the final outcome of a particular behaviour. Attitude refers to circumstances that may assist or prevent performance of the behaviour (Ajzen, 2002).

Attitude directly influences decision-making and also is central to a buyer's shopping behaviour. On the other hand, a consumer's attitude towards online shopping refers to the psychological state in terms of making purchases over the Internet. Consequently, the group with a more positive attitude should be the target market (Shwu-Ing, 2003). Unlike in developed countries, where the influence of e-retailing markets has been indicated to effective, online shopping has been slow to take off in developing countries (Global Internet Report, 2016). It is proof by the study of Salem Ur Rahman, (2018) where online purchasing behaviour phenomena is still in its infancy in many developing countries and need more attention to reach out to the true potential's consumer of ecommerce. Measuring attitude at developing countries is deemed important as predictor of behavioural intention (Mutaz et al., 2015).

\section{Links between consumer attitude and online purchase intention}

There are several studies on attitude from developing countries that are focused on family takaful schemes (Husin and Rahman, 2013), complaints (Zhao and Othman, 2011), digital piracy of movies (Phau, Lim, Liang \& Lwin, 2014), store brands (Diallo, Chandon, Cliquet and Phillippe, 2013) and mobile phones (Petruzzellis, 2010). From the findings, it can be concluded that attitude is crucial to determine consumer decision to perform certain behaviors particularly in developing countries.

The link between attitude and online purchase intention is also significant in a few developed countries. For instance, a study by Lu, Chang and Chang (2014) found that the consumer attitude toward a blogger's sponsored recommendations positively influence purchase intention. The analysis revealed that when a blogger provides recommendation on a certain product in their post with high brand awareness, consumers portrayed a highly positive attitude toward the recommendation post, and the purchase intention can increase.

Similarly, a study by Eom, Seock and Hunt (2019) among 286 undergraduate students from two universities in United states of America on purchase intention of luxury brands indicated that female adult brand's conscientiousness influence the consumption behavior toward luxury brands. 
INTERNATIONAL JOURNAL OF ACADEMIC RESEARCH IN BUSINESS AND SOCIAL SCIENCES Vol. 10, No. 5, May, 2020, E-ISSN: 2222-6990 @ 2020 HRMARS

Thus, from the above, it can be construed that the attitude of consumers may affect their intention on online purchasing. Therefore, this study proposes the following hypothesis (Figure 1):

H1: consumer attitude towards online has a positive effect on online shopping intention of Halal cosmetic products.

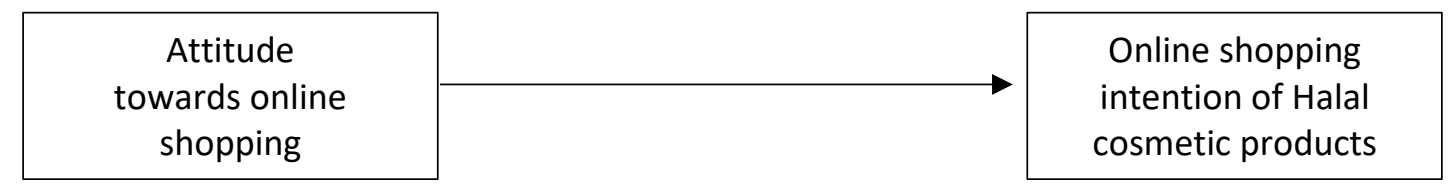

Figure 1. Framework

\section{Methodology}

The study employed survey as the medium to collect data. A survey is best suited for studies that have people as the unit of analysis (Bhattacherjee, 2012). The issue of selecting the optimal number of scale points is still under debate. However, it has been established that seven-point scales can produce reliable results (Weijtersetal, Cabooter \& Schillewaert, 2010). In fact, (Sullivan \& Artino 2013; Habidin, Hashim, Fuzi \& Salleh 2018) also suggested that the seven-point scale is more appropriate and significant than Likert scales. Therefore, this study uses items with a seven-point Likert scales ranging from ( 1 strongly disagree, 7 strongly agree) to measure the items. The final draft of the questionnaire was sent to the experts to be validated (local university academicians and industry experts). Panel of experts of this study were two local university academicians and one industry experts.

This study employed the non-probability sampling, a technique that does not use chance selection procedures. The respondents are consumers who have purchased any products online before. Based on the criteria, a total of 100 persons were purposely selected and used as sample for this study. They are assumed to have first-hand knowledge of the subject matter. Thus, purposive sampling technique was employed in this study. The purposive sampling technique, also called judgment sampling, is the deliberate choice of informant due to the qualities the informant possesses. It is a technique in which an expert or experienced researcher selects the sample based upon some appropriate characteristics of the sample members. Besides, convenience sampling was also used for the purpose of this study in order to obtain those units or people most conveniently available. In essence, this sampling method allows researchers to use a sample that is convenient to obtain besides involving only those that agree to participate.

The Partial Least Square-Structural Equation Modelling (PLSSEM) approach supported by Smart-PLS 3.0 was employed to analyse the research model in this study. PLS-SEM is chosen over CBSEM (covariance-based SEM) due to the philosophy of measurement and the aim of the analysis (i.e., to predict, rather than to confirm), in keeping with the suggestion of Hult et al. (2018). The PLS-SEM approach was executed by assessing the measurement model and the structural model.

\section{Results and Discussion}

Table 1 displays the respondents who were 28 males (28\%) and 72 females (72\%). The majority of the respondents were in the 20-30 age group (41\%) and approximately $9 \%$ were 51 and above years old. It is consistent with the study done by Malaysian Communications and Multimedia 
INTERNATIONAL JOURNAL OF ACADEMIC RESEARCH IN BUSINESS AND SOCIAL SCIENCES Vol. 10, No. 5, May, 2020, E-ISSN: 2222-6990 @ 2020 HRMARS

Commission 2018, where the younger shoppers age below 40 made frequent online purchases than any other group. The population comprised people who work with government, private sector, and students with frequency distributions of $34 \%, 22 \%$, and $21 \%$, respectively. Respondents having a monthly income ranging from RM2001 to RM5000 comprised the majority income group (33\%) followed by those with a monthly income below RM2000 (29\%).

Table 1. Respondents' characteristics

\begin{tabular}{|l|l|l|}
\hline & Frequency & Percentage \\
\hline Gender & & \\
\hline Male & 28 & 28.0 \\
\hline Female & 72 & 72.0 \\
\hline Age & & \\
\hline Below 20 Age & 9 & 9.0 \\
\hline $20-30$ years & 41 & 41.0 \\
\hline $31-40$ years & 28 & 28.0 \\
\hline $41-50$ years & 13 & 13.0 \\
\hline 51 and above & 9 & 9.0 \\
\hline Income & & \\
\hline Below RM2000 & 29 & 29.0 \\
\hline RM2001-RM5000 & 33 & 33.0 \\
\hline RM5001-RM10,000 & 28 & 28.0 \\
\hline RM10,001 and above & 10 & 10.0 \\
\hline Employment & & \\
\hline Government & 34 & 34.0 \\
\hline Private & 21 & 21.0 \\
\hline Self-Employed & 7.0 & 7.0 \\
\hline Unemployed & 15 & 15.0 \\
\hline Students & 22 & 22.0 \\
\hline Pensioner & 1 & 1.0 \\
\hline
\end{tabular}

\section{Measurement Model}

In order to evaluate the reliability criteria, the convergent validity of the measurement model was examined by calculating the composite reliability and AVE. The research method of this study consisted of two latent variables that employ the reflective measurement model on each of the multiple scale items. The loading of all of the factors demonstrated convergent validity and indicated adequate internal consistency. AVEs with values higher than 0.50 indicated that more than 50 per cent of the variance in the measurement items was accounted for by the latent variables (Fornell and Larcker, 1981) (see figure 2). In addition, for structural model estimation, the data results show that attitude to online purchasing positively $(\beta=0.649, p<0.01)$ influence consumers' intentions to purchase online, thus confirming $\mathrm{H} 1$ (see figure 3 ). 


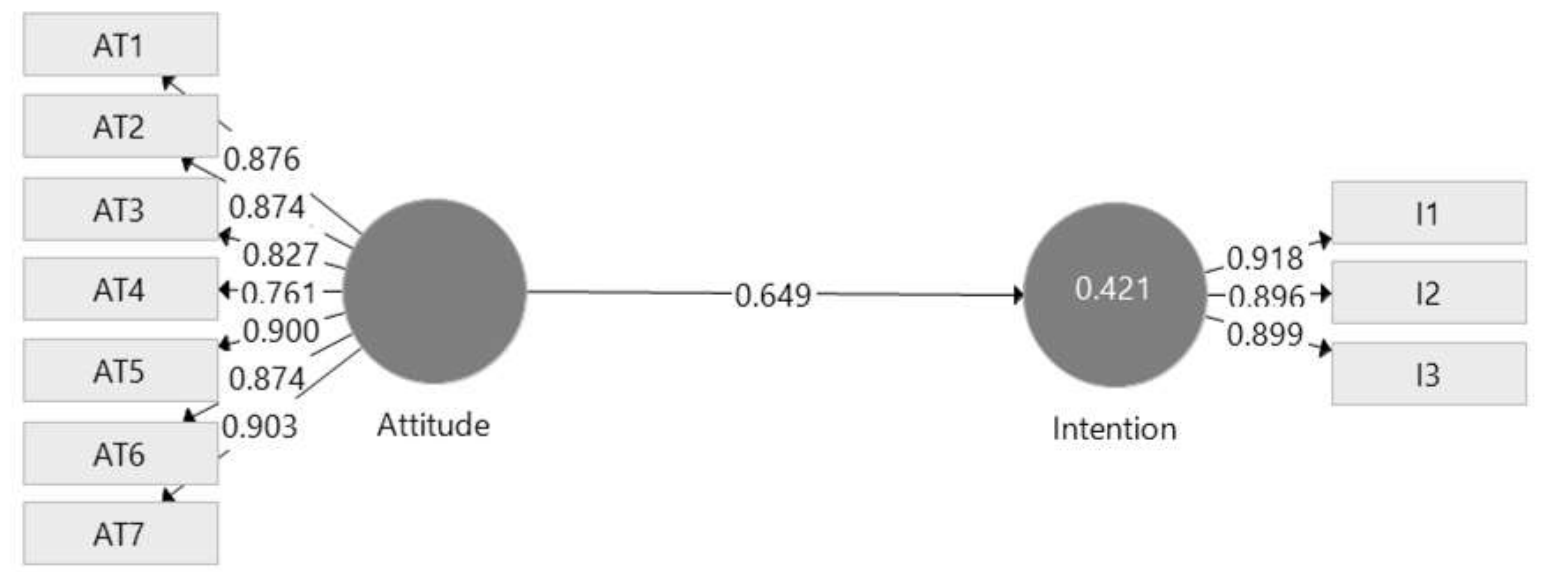

Figure 2. Measurement model

Table 2 shows the internal consistency reliability, convergent validity, and discriminant validity of the construct measures in the measurement model. Reliability of the constructs was inspected using Cronbach's alpha and composite reliability. Table 2 shows the readings of Cronbach's alpha for construct attitude (0.941) and intention (0.889). Meanwhile, the composite reliability for attitude (0.952) and intention (0.931) which all surpassed the boundary of 0.70 (Hair et al., 2014), signifying a strong reliability among the measures.

Table 2. Reliability and Validity Analysis

\begin{tabular}{|c|c|c|c|c|c|}
\hline Factors & Items & Item loadings & $\begin{array}{c}\text { Cronbach's } \\
\text { Alpha }\end{array}$ & $\begin{array}{c}\text { Composite } \\
\text { Reliability } \\
\text { (CR) }\end{array}$ & $\begin{array}{c}\text { Average } \\
\text { Variance } \\
\text { Extracted } \\
\text { (AVE) }\end{array}$ \\
\hline Attitude & & & 0.941 & 0.952 & 0.741 \\
\hline & AT1 & 0.876 & & & \\
\hline & AT2 & 0.874 & & & \\
\hline & AT3 & 0.827 & & & \\
\hline & AT4 & 0.761 & & & \\
\hline & AT5 & 0.900 & & & \\
\hline & AT6 & 0.874 & & & \\
\hline & AT7 & 0.903 & & & \\
\hline Intention & & & 0.889 & 0.931 & 0.818 \\
\hline & I1 & 0.918 & & & \\
\hline & I2 & 0.896 & & & \\
\hline & I3 & 0.899 & & & \\
\hline
\end{tabular}

Table 3 demonstrates that the readings of the associations between all factors were not above the critical value of 0.85 . Discriminant validity was assessed with thresholds of 0.85 , which has been acknowledged as the Fornell-Larcker criterion (Dijkstra \& Henseler, 2015). Furthermore, all constructs had provided evidence of satisfactory discriminant validity. 
INTERNATIONAL JOURNAL OF ACADEMIC RESEARCH IN BUSINESS AND SOCIAL SCIENCES

Vol. 10, No. 5, May, 2020, E-ISSN: 2222-6990 @ 2020 HRMARS

Table 3. Mean, standard deviation and discriminant validity

\begin{tabular}{|l|l|l|}
\hline & Attitude & Intention \\
\hline Attitude & 0.861 & \\
\hline Intention & 0.649 & 0.905 \\
\hline
\end{tabular}

\section{Structural Model}

The significance of path coefficients in the structural model was evaluated via the $95 \%$ biascorrected and accelerated bootstrap confidence intervals with 5000 re-samples. The bootstrapping procedure shows that the direct effects of attitude and intention is significant for the relationship between constructs (see Table 4). The standardised beta coefficients reveal that consumer attitude was seen to significantly affect online purchase intention (beta $=0.649, \mathrm{t}$-value $=7.111, p<0.05$ ). Thus, hypothesis $\mathrm{H} 1$ is supported (see table 3 and figure 3 ).

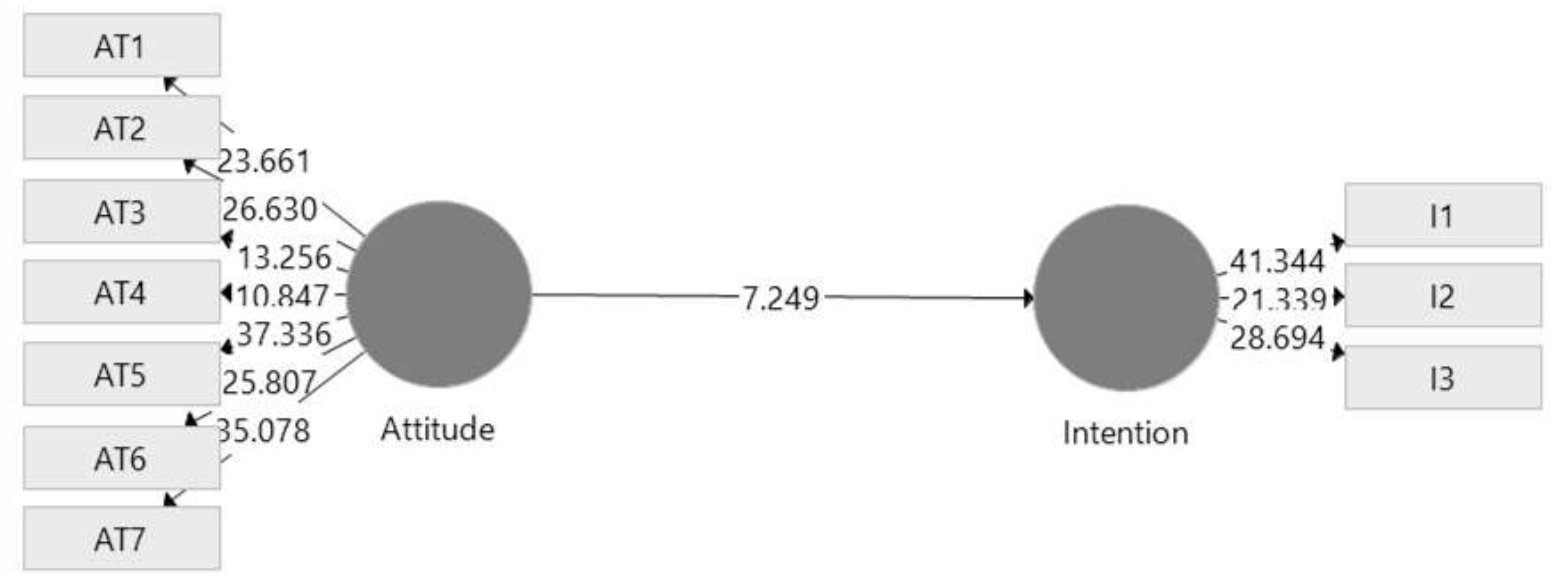

Figure 3. Structural Model

Table 4. Bootstrapping result

\begin{tabular}{|l|l|l|l|l|l|l|}
\hline & $\begin{array}{l}\text { Standard } \\
\text { Beta } \\
\text { Coefficient }\end{array}$ & $\mathrm{T}$-Value & $\mathrm{P}$ Value & $\mathrm{R}^{2}$ & $\mathrm{Q}^{2}$ & $\mathrm{f}^{2}$ \\
\hline $\begin{array}{l}\text { H1: Attitude } \rightarrow \\
\text { Intention }\end{array}$ & 0.649 & 7.111 & 0.000 & 0.421 & 0.312 & 0.728 \\
\hline
\end{tabular}

Based on the blindfolding procedure with an omission distance of 7, a predictive relevance in the structural model is well-secured as a cross validated redundancy result (the Stone-Geisser test, Q2) of the endogenous variable was greater than $0(Q 2=0.312)$ (Chin, 1998). Furthermore, its overall model fit by using the standardised root mean square residual (SRMR $=0.060$ ) as an index for model validation was beneath 0.08 and thus considered satisfactory ( $\mathrm{Hu}$ and Bentler, 1999). Besides that, the $R^{2}$ of the endogenous variable was 0.421 , signifying that $42.1 \%$ of the variance in intention to online purchase is explained by the attitude of consumer. The effect size between attitude and intention variable is of medium effect which size is $0.728 . f^{2}$ values are categories in three which small (0.02), medium (0.15) and large (0.35) (Hair et al., 2016) (see table 4). 


\section{Limitations}

The limitations of the present research are three-fold. First, the data collection was restricted to Malay. A more representative data from different races are required for more reliable data.

Furthermore, the combination of qualitative and quantitative research with a larger sample size of respondent is recommended to better understand the current scenario of online shopping attitude in Malaysia. Third, additional independent measures should be taken into consideration in order to understand the primary determinant factors related to consumer attitude towards online shopping behaviour in Malaysia.

\section{Conclusion}

In line with the discussed literature review, the empirical findings support the validity of the hypothesized model in this study. Overall, the results support the validity of the developed model. The results show that the direct effects of attitude and intention is significant for the relationship between constructs (see Table 4). It reveals that consumer attitude was seen to significantly affect consumer online purchase intention. The effect size between attitude and intention variable is a medium effect which size is 0.728 . It is consistent with previous study (Harn, Khatibi and Ismail, 2006) the level of consumer attitude towards online shopping still at the beginning stage as compared to developed countries. Thus, further research should be implemented in order to better understand what constitutes consumer attitudes in Malaysia.

Notwithstanding these concerns, the present study advances our knowledge of the nature of the relationships among attitude and online shopping. It also fills the gap in understanding the consumer attitude and online purchase intention. this study also contributed to the current body of knowledge regarding the effects of consumer attitude on the formation of online purchase intention halal cosmetic products. It is hoped that this finding will propel other studies into finding out more on consumer behavior and its decision-making characteristics when making online purchases.

\section{Acknowledgement}

The researcher would like to thank the Faculty of Technology Management and Technopreneurship (FPTT), Universiti Teknikal Malaysia Melaka and Universiti Teknologi MARA Melaka for the opportunity given in order to run this study.

\section{Corresponding Author}

Roszi Naszariah Nasni Naseri; Faculty of Technology Management \& Technopreneurship, Universiti Teknikal Malaysia Melaka 75350 Ayer Keroh, Melaka, MALAYSIA and Universiti Teknologi MARA Melaka; Email: roszinaseri@gmail.com.

\section{References}

Ajzen, I. (1991). The theory of planned behavior. Organizational behavior and human decision processes, 50(2), 179-211.

Altuna, O. K., \& Konuk, F. A. (2009). Understanding consumer attitudes toward mobile advertising and its impact on consumers' behavioral intentions: A cross-market comparison of United States and Turkish consumers. International Journal of Mobile Marketing, 4(2), 43-51. 
INTERNATIONAL JOURNAL OF ACADEMIC RESEARCH IN BUSINESS AND SOCIAL SCIENCES

Vol. 10, No. 5, May, 2020, E-ISSN: 2222-6990 @ 2020 HRMARS

Bauer, B. S. J., Reichardt, T., \& Neumann, M. M. (2005). Driving consumer acceptance of mobile marketing: A theoretical framework and empirical study. Journal of Electronic Commerce Research, 6(3), 181-192.

Bhattacherjee, A. (2012). Social Science research principles, methods, and practices. $2^{\text {nd }}$ edition, Zurich, Switzerland: creative commons attribution.

Blackwell, R. D., Miniard, P. W., \& Engel, J. F. (2001). Consumer behavior (9th ed.). Ohio: USA.: SouthWestern Thomson Learning.

Butt, I., Tabassam, S., Chaudhry, N. G., \& Nusair, K. (2016). Using technology acceptance model to study adoption of online shopping in an emerging economy. The Journal of Internet Banking and Commerce, 21(2).

Carroll, A., Barnes, S. J., Scornavacca, E., \& Fletcher, K. (2007). Consumer perceptions and attitudes towards SMS advertising: recent evidence from New Zealand. International Journal of Advertising, 26(1), 79-98.

Chin, S. L., \& Goh, Y. N. (2017). Consumer purchase intention toward online grocery shopping: View from Malaysia. Global Business and Management Research, 9(4s), 221-238.

Chin, W. W. (1998). The partial least squares approach to structural equation modeling. Modern methods for business research, 295(2), 295-336.

Chiu, Y. B., Lin, C. P., and Tang, L. L. (2005). Genders differs: assessing a model of online purchase intention in e-tail service. International Journal of Service Industry Management Vol. 16. No. 5 pp. 416-435.

Chowdhury, H. K., Parvin, N., Weitenberner, C., \& Becker, M. (2006). Consumer attitude toward mobile advertising in an emerging market: An empirical study. International Journal of Mobile Marketing, 1(2), 33-42.

Chua, A. P. H., Khatibi, A., \& Ismail, H. B. (2006). E-commerce: a study on online shopping in Malaysia. Journal of Social Science, 13 (3), 231-242

Diallo, M. F., Chandon, J. L., Cliquet, G., and Philippe, J. (2013). Factors influencing consumer behaviour towards store brands: evidence from the French market. International Journal of Retail \& Distribution Management, 41 (6), 422-441.

Digital. (2019). All the data and trends you need to understand internet, social media, mobile, and ecommerce behaviour in 2019. Available at: www.slideshare.net/datareportal/digital2019malaysia-january-2019-vol. Accessed 2 April 2020.

Dijkstra, T. K., \& Henseler, J. (2015). Consistent partial least squares path modeling. MIS quarterly, 39(2).

Eom, H. J., Seock, Y., \& Hunt, P. (2019). Factors influencing purchase intention toward luxury fashion brands. Journal of Marketing Management and Consumer Behavior, 2(4), 1-16. doi:10.31274/itaa_proceedings-180814-16

Euromonitor International. (2017). Beauty Personal Care Market Report 2017. Available at: http://www.euromonitor.com/beauty-and-personal-care. Accessed on $5^{\text {th }}$ June 2018

Euromonitor International. (2011). Color Cosmetics in Malaysia [On-line] Available www.euromonitor.com

Fornell, C., and Larcker, D. F. (1981). Evaluating structural equation models with unobservable variables and measurement error. Journal of Marketing Research, Vol. 18 No. 1. Pp. 39-50. 
INTERNATIONAL JOURNAL OF ACADEMIC RESEARCH IN BUSINESS AND SOCIAL SCIENCES

Vol. 10, No. 5, May, 2020, E-ISSN: 2222-6990 @ 2020 HRMARS

Global Internet Report. (2016). Available at www.internetsociety.org/globalinternetreports2016/wp.content/uploads/2016/11/1506_GIR _2016-VI.pdf. (accessed 30 March 2020).

Habidin, N. F., Hashim, S., Fuzi, N. M., and Salleh, M. I. (2018). Total productive maintenance, kaizen event, and performance. International Journal of Quality \& Reliability Management 35 (9): 1853-1867.

Hair, F. J., Sarstedt, M., Hopkins, L., \& Kuppelwieser, G. V. (2014). Partial least squares structural equation modeling (PLS-SEM) An emerging tool in business research. European Business Review, 26(2), 106-121.

Halcos. The new global business wave. (2011). [Online]. Available: http://www.halcos.org [5]

Harn, A. C. P., Khatibi, A., Ismail, H. (2006). E-commerce: A study on online shopping in Malaysia. J. Soc.I Sci., 15(5):232-42.

Hornby, C., and Yucel, S. (2009). Halal food going mainstream in Europe: Nestle. Reuters. [Online]. Available: http://reuters.com/article/2009/11/17/idINIndia-44025720091117

Hu, L. T., Bentler, P. M. (1999). Cut off criteria for fit indexes in covariance structure analysis: conventional criteria versus new alternatives. Struct. Equ. Model. 6 (1), 1 e55

Hult, G. T. M., Hair Jr, J. F., Proksch, D., Sarstedt, M., Pinkwart, A., \& Ringle, C. M. (2018). Addressing endogeneity in international marketing applications of partial least squares structural equation modelling. Journal of International Marketing, 26(3), 1-21.

Husin, M. M., \& Rahman, A. A. (2013). What drives consumers to participate into family takaful schemes? A literature reviews. Journal of Islamic marketing, 4 (3), 264-280.

International Trade Administration, Department of Commerce, United States. (2016). Asia Personal Care \& Cosmetic Market Guide [On-line] Available:

http://www.trade.gov/industry/materials/AsiaCosmeticsMarketGuide.pdf

Ireland, J., and Rajabzadeh, S. A. (2011), "UAE consumer concerns about halal products", Journal of Islamic Marketing, Vol. 2 No. 3, pp. 274-283.

Jamil, N. A., Mat, N. K. (2011). To investigate the drivers of online purchasing behavioral in Malaysia based on the theory of planned behavior (TPB): A Structural Equation Modeling (SEM) Approach. International Conference on Management, (pp. 453-460)

Sugibayashi, K., Yusuf, E., Todo, H., Dahlizar, S., Sakdiset, P., Arce, F. Jr., and See, G. L. (2019). Halal Cosmetics: a review on ingredients, production, and testing methods. Cosmetics 6,37; doi:10.3390/cosmetics6030037

Korzaan, M. L. (2003). Going with the flow: Predicting online purchase intentions. Journal of Computer Information Systems, 43(4), 25-31.

Lamb, C. W., Hair, J. F., \& McDaniel, C. (2014). Marketing. Mexico, D.F: Cengage Learning.

Lee, S. F., Tsai, Y. C., \& Jih, W. J. (2006). An empirical examination of customer perceptions of mobile advertising. Information Resources Management Journal, 19(4), 39-55.

Lowe. (2010). On steady demand drives halal cosmetics industry. Gulf News. [Online]. Available: http://gulfnews.com/business/retail/steady-demand-drives-halal-cosm etics-industry1.641165

Lu, L., Chang, W., \& Chang, H. (2014). Consumer attitudes toward blogger's sponsored recommendations and purchase intention: The effect of sponsorship type, product type, and brand awareness. Computers in Human Behavior, 34, 258-266. doi:10.1016/j.chb.2014.02.007 
INTERNATIONAL JOURNAL OF ACADEMIC RESEARCH IN BUSINESS AND SOCIAL SCIENCES

Vol. 10, No. 5, May, 2020, E-ISSN: 2222-6990 @ 2020 HRMARS

MATRADE. (2011). [Online]. Available: http://www.matrade.gov.my/en/foriegn-buyers-section/69industry-write-upproducts/519-chemicals-a-chemical-products

MATRADE. (2012). Malaysia External Trade Development Corporation [On-line] Available http://www.matrade.gov.my

MCMC. (2017). Internet Users Survey 2017: Statistical Brief Number Twenty One. Malaysian Communication and Multimedia Commission. ISBN 1823-2523

MCMC. (2018). e-commerce consumer survey 2018. https://www.mcmc.gov.my accessed 1 April 2020.

Ministry of Science, Technology and Innovation. (2018). An update on Malaysian Standards on Halal. Citefast.com/styleguide.php?style=APA\&sec=government

Mordor Intelligence. (2019). Halal cosmetic industry. www.mordorintelligence.com/industryreports/halal-cosmetic-products-market. Accessed 1 April 2020.

Muniandy, R., Al-Mamun, A., Permarupan, P. Y., \& Zainol, N. R. (2014). Factors Influencing Consumer Behavior: A study among University students in Malaysia. Asian Social Science. 10 (9), 18-25.

Mutaz, M., Al-Debei, M. N. A., and Ashouri, M. I. (2015). Consumer attitudes towards online shopping: the effects of trust, perceived benefit and perceived web quality. Internet Research Vol. 25, No. 5, pp. 707-733.

Nadia, B. (2019). Halal beauty next big thing. www.nst.com.my/lifestyle/flair/2019/05/492252/halalbeauty-next-big-thing. Accessed 1 April 2020.

Norzaidi, M. D., Hazni, A. A., Hana, N. B., and Fazila, S. (2012). Identifying the determinant attributes of Halal Cosmetics product that influence its positioning strategy in Malaysian Market. Journal of Applied Sciences Research, 8 (1), 301-313.

O'Cass, A., and Fenech, T. (2003). Web retailing adoption: exploring the nature of internet users web retailing behaviour. Journal of Marketing, Vol. 10 No. 2, pp. 81-94.

Opportunity Malaysia: Mission to Malaysia. (2015). [Online]. Available: http://www.malaysiamission.com

Pavlou, P. A. (2003). Consumer acceptance of electronic commerce: Integrating trust and risk with the Technology Acceptance Model. International Journal of Electronic Commerce, 17(3), 101134.

Petruzzellis, L. (2010). Mobile phone choice: technology versus marketing. The brand effect in the Italian market. European Journal of Marketing, 44 (5), 610-634.

Pew Research (2018). Muslims are projected to be the world's fastest growing major religious group in the decades ahead. Retrieved on July 2018 from http://www.pewresearch.org/facttank/2017/12/26/17-striking-findings-from-2017/

Phau, I., Lim, A., Liang, J., \& Lwin, M. (2014). Engaging in digital piracy of movies; a theory of planned behaviour approach. Internet Research, 24 (2), 246-266.

Raman, P. (2019). Understanding female consumers' intention to shop online. Asia Pacific Journal of Marketing and Logistics.

Rezaei, S., and Ismail, W. K. W. (2012). Online repatronage intention: an empirical study among Malaysian experienced online shoppers. International Journal of Retail \& Distribution Management, Vol. 42 No. 5, pp. 390-421.

Salama. (2014). Malaysia's Halal Industry. Retrieved from halalfocus.net/malaysias-halal-industy

Salem Ur Rahman. (2018). Motivations and barriers to purchasing online: understanding consumer responses. South Asian Journal of Business Studies, Vol. 7. No. 1 pp. 111-128. 
INTERNATIONAL JOURNAL OF ACADEMIC RESEARCH IN BUSINESS AND SOCIAL SCIENCES

Vol. 10, No. 5, May, 2020, E-ISSN: 2222-6990 @ 2020 HRMARS

Shwu, I. (2003). The relationship between consumer characteristics and attitude toward online shopping. Marketing Intelligence \& Planning, 21(1), 37-44.

So, W. C., Wong, D. T. N., \& Sculli, D. (2005). Factors affecting intentions to purchase via the internet. Industrial Management \& Data Systems, 105(9), 1225-1244.

Sullivan, G. M., and Artino, A. R. (2013). Analyzing and interpreting data from likert-type scales. Journal of Graduate Medical Education, 5 (4): 541-542.

Swidi, A., Wie, C., Hassan, M. G., Al-Hosam, A., \& Kassim, M. A. W. (2010). The mainstream cosmetics industry in Malaysia and the emergence, growth and prospects of Halal cosmetics. The Third International Conference on International Studies (ICIS 2010), Sintok: Universiti Utara Malaysia.

Weijters, B., Cabooter, E., and Schillewaert, N. (2010). The effect of rating scale format on response styles: the number of response categories and response category labels. International Journal of Research in Marketing, 27 (3): 236-247.

Yousef, D. K. (2010). Halal food numbers look tasty. Gulf News. [Online]. Available: http://gulfnews.com/business/general/halal-food-numbers-look-tasty1.679007

Zhao, W., \& Othman, M. N. (2011). Predicting and explaining complaint intention and behaviour of Malaysian consumers: an application of the planned behaviour theory. Advances in international marketing, 21, 229-252. 